\title{
Off-farm labour supply and production efficiency of farm household in rural Southwest Nigeria
}

Adebayo M Shittu

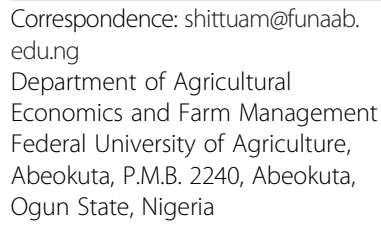

Correspondence: shittuam@funaab. edu.ng

Department of Agricultural Economics and Farm Management Federal University of Agriculture, Abeokuta, P.M.B. 2240, Abeokuta, Ogun State, Nigeria

\begin{abstract}
This study examines the influence of off-farm employment on production efficiency of farm household in Southwest Nigeria. The study was based on primary data collected from a cross-section of 489 rural farm households, drawn by multi-stage random sampling from Ogun and Oyo States, in Southwest Nigeria. The data was analysed by descriptive and econometric techniques, including specification and estimation of a conditional revenue frontier and a production inefficiency equation. The results showed that $47.1 \%$ of the rural farm households had some of their members involved in off-farm activities with a typical member devoting $34.3 \%$ of his/her work efforts to off farm activities, while off farm activities contributed $27.6 \%$ of a typical farm household's labour income (N282, 263.54 in 2005/2006). Increase in off-farm labour supply was found to be associated with significant $(p<0.01)$ reduction in production in-efficiency among the rural farm households. The study also found that farm household production efficiency is significantly enhanced by increasing the share of tree crops and livestock in farm household farming activities, having access to land by leasing and operating a much more consolidated landholdings. However, remittances from rural out-migrants do not significantly affect rural farm household production efficiency.
\end{abstract}

JEL code: J2, Q1, R2

Keywords: Off-farm labour supply; Production efficiency; Nigeria

\section{Background}

Nigeria, a nation once flaunted as the "Giant of Africa", is at present battling with a rising incidence of unemployment and poverty, with as much as $21.1 \%$ of the economically active people reported as unemployed in 2010 (NBS, 2011) while $64.4 \%$ of the populace lived below the US\$1.25 income poverty line in 2008 (UNDP, 2010). The poor in Nigeria are reported to be predominantly rural dwellers and households that rely mainly on agricultural means of sustenance (World Bank, 2000; FOS 1999; NBS (2012); Babatunde, et al. 2008). Moreover, socio-economic conditions in most rural communities in Nigeria are generally poorer that what obtains in the cities: hence rural-urban migration has been a strategy adopted by many in a bid to escape poverty (Okali et al., 2001).

Evidence in literature suggest that rural urban migration in Nigeria is massive, with as much as about $38 \%$ of the economically active members of the rural farm families in Southwest Nigeria reported to have migrated to the urban centres (Shittu, 2011). This massive rural out-migration has been a major cause of rapid urbanisation and 
congestion of Nigerian cities; leading to urban squalor and poverty, housing shortages, and pollution (DFID, 2004), while many that could not find job sometimes resort to crime making most Nigerian cities very dangerous, especially at nights (USAID, 2002). Moreover, rural out-migrants in Nigeria are predominantly the youths, male-folks and educated members of the rural farm households as well as artisans and other skilled workers in the rural sector (Okali et al., 2001; DFID, 2004, Shittu, 2011). Thus, ruralurban migration in Nigeria has meant that the rural areas are often left with a demographically unbalanced population of women, younger children, and older people (Okali et al., 2001; DFID, 2004). It also denies the rural sector the much-needed human capital, reduces availability of farm labour (Ogwumike and Aramolaran, 2000), and thereby tends to weaken productivity and income levels in the sector. The fact that unemployment level in Nigeria is now much higher in the urban sector than what obtains in the rural areas is also worrisome.

Against the above background, there is a rising believe among policy analysts, academia and government functionaries that provision of urban-type employment opportunities in the rural areas may be a veritable means of addressing the multifaceted problem of poverty, urbanisation and unemployment in Nigeria. This view is supported by FAO (1998), Matshe and Young (2004), and many others that have observed that given the limitations imposed by the fixed stock of land and increasing urbanisation, provision of opportunity for involvement of members of rural farm households in rural non-farm activities might turn out to be a means of creating favourable conditions to reduce poverty in the rural areas. Goldsmith, et al. (2004) also observed that growth in the rural non-farm activities might also be used to stem rapid rural-urban migration and the attendant urban poverty in most developing countries.

This paper presents empirical evidences on the types of off-farm employment opportunities available to rural farm households in Southwest Nigeria, returns to household labour supply use within the rural farm and non-farm sectors, and implications of the labour use patterns on farm household production efficiency in the study area. The remaining part of the paper is organised thus: A brief review of literature is presented in Section 2, followed by the theoretical framework Section 3. The study methodology is presented in section 4 followed by the results and their discussions in section 5 , while the final section summaries the main evidences and conclusions from the study.

\section{Literature review}

A wide range of empirical studies have examined issues relating to off-farm labour supply and the implications on household welfare. Lanjouw and Lanjouw (2000), in a review of some of these studies, observed that while the rural non-farm sector was traditionally viewed as a low-productivity sector producing low quality goods that are expected to wither away as a country develops, recent years have seen a shift away from this position towards recognition of the fact that the rural non-farm sector can, and often does, contribute to economic growth, rural employment, poverty reduction, and a more spatially balanced population distribution.

The most common evidence from most studies of off-farm work among farm households has been that income from off-farm work accounts for significant and increasing proportion of total income of farm households in the developing countries (Anderson 
and Leiserson, 1984; Jacoby 1993; Newman and Gertler, 1994; Lanjouw, 2000; Escobal, 2001; Shittu, et al., 2006; Haggblade, et al. 2010; Shittu, 2011; and many other). Recent estimates by Haggblade et al. (2010) put the non-farm share of the total income of rural households in the developing countries in the range of $35 \%$ and $50 \%$, with the contributions among rural households in sub-Saharan Africa expected to rise significantly in the coming years given the increasing population growth and limited agricultural productivity growth in the region.

Evidences in literature suggest that a key motivation leading to off-farm labour supply among farm households in both the developed and the developing country has been the desire to have a diversified sources of income and manage risk (Chang and Mishra (2008). Hazell and Hojjati (1995) as well as Chavas, et al., (2005), among others, have also reported that given the very weak capital market in most developing countries, many farm households in the often resort to off-farm work to raise cash with a view to relaxing their cash flow and liquidity constraints. This view is supported by evidences in Stampini and Davis (2009) as well as Pfeiffer, et al. (2009) that reported that households engaged in off-farm activities were able to spend significantly more on seeds, services, hired labour, and livestock inputs, which confirms that off-farm income relaxes credit constraints in agriculture.

Focusing on impacts of off-farm work, available evidence suggests that increased participation in off-farm work among members of farm households is associated with higher incomes as well as improved food consumption, nutrition and food security (Chang and Mishra, 2008; Babatunde and Qaim, 2010; Owusu et al., 2011). It was also reported as linked to significant reduction in variance of total income (Schultz, 1990) as well as reduction in intensity of agricultural production (Phimister and Roberts, 2006; Huang et al., 2009; Shi et al., 2011; Owusu et al., 2011) with positive environmental impacts due to reduction in the use of certain agrochemicals that impact negatively on the environment (Phimister and Roberts, 2006).

Despite the common evidences that income from non-farm sources helps in relaxing financial constraints on farm households and enhancing farm investment, evidences on the impacts on domestic food supply, production efficiency and household welfare, in general, remain quite conflicting. For example, while Lien et al., (2010) reported that off-farm income had a positive effect on farm output but no systematic effect on farm technical efficiency, Pfeiffer, et al. (2009) reported that off-farm income has negative effect on agricultural output and the use of family labour on the farm, but positive impact on use of purchased inputs and confer a slight efficiency gain on farm households participating in off-farm activities. Shi et al. (2011), however, found that the negative lost-labour effect is much stronger than the (small) positive income effect while Holden et al. (2004) reported that access to non-farm income in less favoured Ethiopian highlands reduces farm households' incentives to invest in conservation and this leads to more overall soil erosion and more rapid land degradation even though intensity of production is reduced.

While Chang and Wen (2011) reported that off-farm work is not necessarily associated with lower (or higher) technical efficiency, they noted that farmers with off-farm work face higher production risk. They reported, however, that for farmers in the lower percentiles of the efficiency distribution, those with off-farm work are more efficient than their counterparts without off-farm work. Similarly, Chavas, et al. (2005), in a 
study of farm households in Gambia found that a significant part of a substantial allocative inefficiency that exists in the production systems of the farm households comes from inefficiency in labour allocation between farm and non-farm activities. They noted however, that in the presence of weak capital market in Gambia, off-farm activities acts to relax cash flow and liquidity constraints.

Wandschneider (2003) in a review of several studies of non-farm employment in developing countries of Africa and South Asia as well as the Transition Economies observed that a significant proportion of rural households and entrepreneurs in the studied regions do not only lack many of the required assets to successfully engage in non-farm employment, but also operate in a relatively adverse environment, characterised by limited opportunities both within and outside the farm economy. Consequently, he concluded that diversification into non- farm economic activities in all studied regions were largely out of necessity (distress-push) rather than as a response to remunerative wage employment and high return business opportunities (demandpull). Similarly, Lanjouw (2001) in a study in rural El Salvador found that the poor were mainly engaged in "last resort" non-farm activities.

In summary, evidences in existing body of literature seem to suggest that while offfarm income accounts for significant and increasing share of total income of rural farm households in the developing countries, the implications on efficiency of household resource allocation, food supply and overall household welfare remain uncertain, and vary widely by locality and socio-economic environments. While for some, off-farm labour supply might be a response to remunerative wage employment and high return business opportunities, for many, working off-farm may be borne out of necessity to seek ways and means to relax credit constraints, raise supplementary income to complement what obtains from the farm most especially during lean seasons, or otherwise. Therefore, bearing in mind the likely presence of rigidity in rural off-farm labour market and/or reliance on joint technology for farm and off-farm activities among the ruralfolks, more empirical evidences are required to assess the implications of off-farm labour supply on efficiency of resource allocation and household welfare. This study is an effort along this direction, with focus on resource poor farm households in rural Southwest Nigeria.

\section{Conceptual framework}

The conceptual framework for this study is based on a variant of agricultural household models developed in Chavas, et al. (2005). Reliance on agricultural household modelling framework is in recognition of the fact that the semi-commercial nature of smallholder agriculture in the developing countries makes it imperative that the production, consumption and labour allocation decisions of the farm households are interdependent. The framework is further justified given the well-documented evidences of labour market imperfection in the developing countries and/or the fact that farm households may rely on joint technology for their farm and off-farm activities. The framework, as developed by Chavas, et al. (2005), may be summarised as follows:

Consider a farm household with $m$ family members making production, consumption, and labour allocation decisions during a specific time period. Let $\mathbf{F}=\left(F_{1}, \ldots F_{m}\right)$ and $\mathbf{L}=\left(L_{1}, \ldots, L_{m}\right)$ be the amount of labour supplied by the $\mathrm{m}$ family members in 
pursuit of the household farm and off-farm activities respectively; and $H$, the amount hired labour hired and used in conjunction with the non-labour inputs $x$ (including land) and $\mathbf{F}$ to produce the vector of farm output, $y$ in addition to the off-farm income, $\mathrm{N}$ earned from $\mathbf{L}$. The technology facing the household is represented by the feasible set $X$, where $(x, \mathbf{F}, H, \mathrm{~L} ; \mathrm{y}, N) \in X$ means that inputs $(x, \mathbf{F}, H, \mathrm{~L})$ can feasibly produce outputs $(\mathrm{y}, N)$, and farm and off-farm labour productivity is allowed to vary across family members.

If the total amount of time available to any family member over a time period is $\mathrm{T}$; and the $m$ family members can allocate their time between leisure activities $I=\left(l_{1}, \ldots\right.$, $\left.1_{m}\right)$, on-farm labour $\mathrm{F}=\left(F_{1}, \ldots, F_{m}\right)$, and off-farm employment $\mathrm{L}=\left(L_{1}, \ldots, L_{m}\right)$, the time constraint facing each family member can be written as:

$$
I_{i}+F_{i}+L_{i}=T
$$

If the farm-household consumes goods $\mathbf{z}$, purchased at market prices $\mathbf{q}$, and faces competitive markets for its products and inputs with $\mathbf{p}$ as the price vector for farm outputs $\mathbf{y}, \mathbf{r}$ the price vector for non-labour inputs $x$, and $w$ the wage rate for hired labour $H$, the household consumption decisions would be made subject to the budget constraint, which requires that consumer expenditure $\left(\boldsymbol{q}^{\prime} \boldsymbol{z}\right)$ cannot exceed the net farm income $\left(\mathbf{p}^{\prime} \mathbf{y}-\boldsymbol{r}^{\prime} x-w H\right)$ plus the non-farm income $(N)$. That is:

$$
q^{\prime} \boldsymbol{z} \leq\left(\mathbf{p}^{\prime} \mathbf{y}-\boldsymbol{r}^{\prime} x-w H\right)+N
$$

Therefore, if it is assumed that household members make production, consumption, and labour allocation decisions under cooperative bargaining, and that members' preferences can be aggregated into a non-satiated and quasi-concave "social utility function" function $U(\boldsymbol{z}, \boldsymbol{l})$ defined over $(\boldsymbol{z}, \boldsymbol{l}) \geq 0$, reflecting their relative bargaining power; then, the household decisions may be analysed based on the following optimisation problem:

$$
\max _{\mathbf{x}, \mathrm{F}, \mathrm{H}, \mathrm{L} ; \mathrm{y}, \mathrm{N}} U(\boldsymbol{z}, \boldsymbol{l}): l_{i}+F_{i}+L_{i}=T ; \boldsymbol{q}^{\prime} \boldsymbol{z} \leq \mathbf{p}^{\prime} \mathbf{y}-\boldsymbol{r}^{\prime} x-w H+N ;(x, \mathbf{F}, H, \mathbf{L} ; \mathbf{y}, N) \in X
$$

Chavas, et al. (2005) asserted that under non-satiation of the utility function $U(\boldsymbol{z}, \boldsymbol{l})$, the budget constraint (2) is necessarily binding, and the optimisation problem (3) can be decomposed into two stages: first, choose $(x, \mathbf{F}, H, \mathbf{L} ; \mathbf{y}, N)$; and second, choose $(\mathbf{z}, l)$.

The first stage optimisation with respect to $(x, \mathbf{F}, H, \mathbf{L} ; \mathbf{y}, N)$ can be written as:

$$
\begin{aligned}
\pi(\mathbf{p}, \mathbf{r}, w, \mathbf{T}-\boldsymbol{l}) & =\max _{\mathrm{x}, \mathrm{F}, \mathrm{H}, \mathrm{L} ; \mathrm{y}, \mathbf{N}}\left\{\mathbf{p}^{\prime} \mathbf{y}-\boldsymbol{r}^{\prime} x-w H+N:(x, \mathbf{F}, H, \mathbf{L} ; \mathbf{y}, N) \in X\right. \\
F_{i}+L_{i} & \left.=T-l_{i} ; i=1, \ldots, m\right\}
\end{aligned}
$$

where $(\mathbf{T}-\boldsymbol{l}) \equiv\left(T-l_{1}, \ldots, T-1_{m}\right)$ are the amounts of time the $m$ family members spend working either on or off the farm. Equation (4) establishes profit maximization with respect to the household choice of $(x, \mathbf{F}, H, \mathbf{L}, \mathbf{y}, N)$, with $\pi(\mathbf{p}, \mathbf{r}, w, \mathbf{T}-\boldsymbol{l})$ being the indirect profit function conditional on $(\mathbf{T}-\boldsymbol{l})$.

Chavas, et al. (2005) drew attention to the fact that for a given amount of time allocated to work by household members $(\mathbf{T}-\boldsymbol{l})$, a failure to maximize profit would reduce household income, which would restrict consumer expenditure (from equation (2)), 
and which under non-satiation, would make the household worse-off. Thus, a failure to maximize profit would be inconsistent with household utility maximization.

Furthermore, considering that solution to (4) would yield the profit maximizing input and labour decisions, $x^{*}(p, \mathbf{r}, w, \mathbf{T}-\boldsymbol{l}), \mathrm{F}^{*}(p, \mathbf{r}, w, \mathbf{T}-\boldsymbol{l}), H^{* \prime}(p, \mathbf{r}, w, \mathbf{T}-\boldsymbol{l})$, and $\mathbf{L}^{*}(p, \mathbf{r}, w$, $\mathbf{T}-\boldsymbol{l})$ as well as the profit maximizing outputs decisions, $\mathbf{y}^{*}(p, \mathbf{r}, w, \mathbf{T}-\boldsymbol{l})$ and $N^{* \prime}(p, \mathbf{r}, w$, $\mathbf{T}-\boldsymbol{l})$ that together with the profit function $\pi(\mathbf{p}, \mathbf{r}, w, \mathbf{T}-\boldsymbol{l})$ do not depend on consumption levels $\mathbf{z}$, we find that production decisions are "separable" from consumption decisions. Hence, analysis of the production and consumption decisions of farm households can be undertaken separately as a two stage problem, starting with the profit maximisation problem (4) as a first stage optimisation.

The profit function $\pi(\mathbf{p}, \mathbf{r}, w, \mathbf{T}-\boldsymbol{l})$ and production decisions, $\mathbf{y}^{*}(\boldsymbol{p}, \mathrm{r}, w, \mathbf{T}-\boldsymbol{l})$ and $N^{*}(\boldsymbol{p}, \mathbf{r}, w, \mathbf{T}-\boldsymbol{l})$ are, however, jointly dependent on the amount of time available for work, ( $\mathbf{T}-1)$. Note also that equation (4) includes farm and non-farm activities, both in terms of labour allocation (F and $\mathbf{L}$ ) and income (p'y and $N$ ) at the household level. It involves the general technology $X$, allowing for joint household decisions between farm and non-farm activities. Hence, decisions on labour allocation between farm and off-farm activities are dependent, and have to be jointly resolved within the profit maximisation problem (4). Chavas, et al. (2005) pointed out that examples of jointness in farm and off-farm activities include skills acquired in non-farm employment that improve farm management, and non-farm income that reduces the adverse effects of credit market imperfection on farm decisions.

Now, given that utility maximization (3) implies profit maximization (4) as a first stage optimisation, the second stage decisions with respect to $(z, l)$ becomes:

$$
\left.\max _{z, 1} U(\boldsymbol{z}, \boldsymbol{l}): \boldsymbol{q}^{\prime} \boldsymbol{z} \leq \pi(\mathbf{p}, \mathbf{r}, w, \mathbf{T}-l)\right\}
$$

Equation (5) is a standard utility maximization problem subject to the household budget constraint. Combining the two stages (4) and (5) is fully consistent with utility maximization (3). Chavas, et al. (2005) noted that the profit maximization (4) is the relevant framework to analyse production efficiency at the household level. They observed that in the presence of market imperfections and/or poor managerial skills, it is possible that households may not behave in a way consistent with (4) because they do not or cannot respond to economic incentives. They concluded thus, that economic analysis based on (4) could yield useful insights into the nature and causes of economic inefficiency. They stressed further, that the profit maximization problem (4) implies the following revenue maximization:

$$
\max _{\mathrm{y}, \mathrm{N}} R(\mathbf{p}, x, \mathbf{F}, H, \mathbf{L}, X)=\mathbf{p}^{\prime} \mathbf{y}+N:(x, \mathbf{F}, H, \mathbf{L} ; \mathbf{y}, N) \in X
$$

where $R(p, x, \mathrm{~F}, H, \mathrm{~L}, X)$ is the revenue function, conditional on inputs $(x, \mathrm{~F}, H, \mathrm{~L})$. This suggests that analysis of production efficiency of farm households that exhibits significant off-farm labour market participation can be undertaken by focusing on output decisions, conditional on available inputs ( $x, \mathrm{~F}, H, \mathrm{~L})$. Chavas, et al. (2005) pointed out that equation (6) assumes only well-functioning output markets. And, that this is important in the sense that analysis of farm household production efficiency, such as would be undertaken in this study, remains valid in the presence of factor market imperfections. 
Given a representation of the production possibility frontier of a household involved in both farm and off-farm activities that is characterized by the use of inputs ( $x, \mathrm{~F}, H, \mathrm{~L})$ in producing outputs $(y, N)$. Chavas, et al. (2005) observe that the output based technical efficiency index, TE, is defined as:

$$
T E(x, \mathbf{F}, H, \mathbf{L}, \mathbf{y}, N, X)=\min _{\theta}\{\theta:(x, \mathbf{F}, H, \mathbf{L} ; \mathbf{y} / \theta, N / \theta) \in X, \theta>0\}
$$

Where $0 \leq \mathrm{TE} \leq 1$, and $\mathrm{TE}=1$ when the household is producing on the production frontier and is said to be technically efficient, while $\mathrm{TE}<1$ shows the farm is not technically efficient.

Similarly, the allocative efficiency index, AE, with respect to farm outputs may be defined as:

$$
A E(\mathbf{p}, x, \mathbf{F}, H, \mathbf{L}, X)=\left[\mathbf{p}^{\prime}(\mathbf{y} / T E+N / T E] / R(\mathbf{p}, x, \mathbf{F}, H, \mathbf{L}, X)\right.
$$

where (y/TE, N/TE) is a technically efficient output vector. In general, $0 \leq \mathrm{AE} \leq 1$, where $\mathrm{AE}=1$ represents a revenue maximizing firm that is allocatively efficient with respect to outputs, and $\mathrm{AE}<1$ shows that the farm is not allocatively efficient.

\section{Methods}

\section{Data collection method}

This study was based on primary data obtained in a cross-section survey of rural farm households in Ogun and Oyo states, in the Southwest rainforest zone of Nigeria. The respondent farm households were drawn in a three-stage sampling process that yielded a total 537 rural farm households. These were drawn across 80 randomly selected rural communities/villages in eight randomly selected Local Government Areas (LGAs) among those that are predominantly agrarian and rural in Ogun and Oyo states in Nigeria. The selected LGAs include Obafemi-Owode, Ijebu-North, Remo-North and Yewa South LGAs in Ogun state; and Oluyole, Ibarapa-East, Oyo-West and Saki-West LGAs in Oyo state.

It is instructive to note that in Nigeria, an area is considered urban if its human population is at least 20,000 and/or if it is located within a local government's or state's headquarter town or within the Federal Capital Territory (Okali, et al., 2001), otherwise it is considered rural. However, areas designated as villages/farming communities on the maps of the various LGAs were typically with human population below 3000, and are mostly in remote locations from the urban centres. The study respondents were drawn from these "small" and remote communities. The mean distance ( \pm standard error) of the sampled communities to the nearest town /LGA headquarters was $11.22 \pm$ 0.41 kilometres; with only about half (54.2\%) linked to the nearest town/LGA headquarter by a paved road, $52.7 \%$ linked to the national electricity grid and $43.7 \%$ having access to portable water either through the public tap $(10.7 \%)$ or public borehole (32.6\%) (See: Shittu, 2011).

Relevant data on socio-economic (community and household) characteristics, household labour and other resource use in both farm and non-farm activities during the $2005 / 2006$ production season, and the associated costs, returns, outputs, and prices, among others were collected with the aid of a structured questionnaire/interview schedule. Information supplied by some of the respondents was considered inconsistent 
and/or incomplete, such that only data from 489 farm households were included in the final analysis.

\section{Model specification}

In this study, a stochastic conditional revenue frontier (9) was specified and estimated jointly with a production inefficiency equation (10). The estimated model may be stated as follows:

$$
Y_{i}=f(X, \beta)+v_{i}-u_{i}
$$

where,

$\mathrm{Y}_{\mathrm{i}}$ is logarithm of total household income, including farm income and off-farm labour income ( $\mathrm{N})$,

$\mathrm{X}$ is a vector of the logarithm of explanatory variables, including selected product prices, quantities of conventional inputs used, household labour and hired labour.

$\beta$ is a vector of unknown parameters;

$v_{i}$ is a random disturbance term, which is assumed to be identically, independently and normally distributed with mean 0 and variance $\sigma_{\mathrm{v}}{ }^{2}$, and independent of $\mathrm{u}_{\mathrm{i}}$;

$\mathrm{u}_{\mathrm{i}}$ is a non-negative random variable assumed to account for production inefficiency across farm households, and is assumed to be independently distributed as truncations at zero of the $\mathrm{N}\left(\mathrm{m}_{\mathrm{i}}, \sigma_{\mathrm{u}}^{2}\right)$ distribution; where the means of $\mathrm{u}_{\mathrm{i}}, \mathrm{m}_{\mathrm{i}}$ is defined as follows:

$$
m_{i}=\mathrm{f}\left(Z_{1}, Z_{2}, \ldots \ldots, Z_{k}\right)
$$

Details of variables included in equations (9) and (10) as well as their descriptive statistics based on the study data are presented in Table 1.

\section{A-priori expectations}

A-priori, it is expected that coefficients of all the variables in the conditional revenue frontier will be positive, since increased use of factors and higher prices are expected to lead to increase in farm household income, ceteris paribus. Focusing on the inefficiency equation, however, it is expected that coefficients $Z_{8}$ and $Z_{9}$ would be positive, given that farm fragmentation $\left(Z_{8}\right)$ and having to trek long distances to farm $\left(Z_{9}\right)$ tends to raise production inefficiency. Coefficients associated with education $\left(Z_{3}\right)$ and youth factor $\left(Z_{4}\right)$ as well as those of asset income $\left(Z_{10}\right)$, remittances received from migrants $\left(Z_{11}\right)$ and total credit received $\left(Z_{12}\right)$ are expected to be negative; since education, youthfulness and access to financial capital are expected to enhance productivity (production efficiency) in agriculture. Coefficients of other variables could take on either positive or negative signs depending on their influence on farm household production efficiency.

\section{Results and Discussion}

As background information, Table 2 provides key socio-economic information on the 489 sampled farm households included in the study. As shown on the Table 2, an average household in the sample was composed of six members, three (3) of which were economically active. These households are generally resource poor, with the members jointly cultivating an average of 1.83 hectares of land, and raising an 
Table 1 Descriptive statistics of variables in the Stochastic Revenue Frontier and inefficiency equation

\begin{tabular}{|c|c|c|c|}
\hline Variable & Definition of variables & Mean & Std. error \\
\hline \multicolumn{4}{|c|}{ Variables in the conditional revenue function } \\
\hline$A D L A B$ & Number of economically active adults & 2.88 & 0.23 \\
\hline CHLAB & $\begin{array}{l}\text { Number of children ( }<18 \text { years) supporting household income } \\
\text { generating activities }\end{array}$ & 1.44 & 0.10 \\
\hline HRLAB & Hired labour cost $(\mathrm{N})$ & $25,823.34$ & $2,336.35$ \\
\hline FSIZECRP & Size of arable crop farm $(\mathrm{Ha})$ & 1.27 & 0.02 \\
\hline FSIZETRE & Size of tree crop farm $(\mathrm{Ha})$ & 0.57 & 0.01 \\
\hline ANU & Size of livestock farm (Animal unit) & 0.34 & 0.08 \\
\hline FERT & Quantify of fertilizer (50 kg Bags) & 0.96 & 0.16 \\
\hline TRACTDAY & Tractor services used (Workdays) & 0.45 & 0.05 \\
\hline MATCOS & Cost of other intermediate materials $(\mathrm{N})$ & $11,710.26$ & $1,774.14$ \\
\hline PGARRI & Price of garri (N/kg) & 80.43 & 1.32 \\
\hline PMAIZE & Price of maize grain $(\mathrm{N} / \mathrm{kg})$ & 80.07 & 1.13 \\
\hline PYAM & Price of yam (N per dozen tubers) & $1,110.48$ & 16.11 \\
\hline PEGGS & Price of eggs (N/tray) & 345.51 & 2.24 \\
\hline POIL & Price of palm oil (N/litre) & 91.18 & 1.12 \\
\hline \multicolumn{4}{|c|}{ Variables in the production inefficiency equation } \\
\hline GENDER & Household head is a female ( $\mathrm{Yes}=1, \mathrm{No}=0$ ) & 0.08 & 0.02 \\
\hline NATIVITY & Household head is non-native (Yes $=1, \mathrm{No}=0$ ) & 0.19 & 0.03 \\
\hline HIGHEDU & Years of schooling by the most educated worker in the household & 7.95 & 0.31 \\
\hline YOUTHFAC & Proportion of youths (30 years) in household & 0.52 & 0.03 \\
\hline GENDERFA & Proportion of females in the household & 0.41 & 0.03 \\
\hline PTREE & Proportion of farmland devoted to tree crops & 0.30 & 0.02 \\
\hline PFREHOLD & Proportion of farmland on freehold & 0.62 & 0.03 \\
\hline SIMPSON & Simpson index measure of farm fragmentation & 0.39 & 0.02 \\
\hline DISTANCE & Average distance of farm parcels from home & 3.18 & 0.15 \\
\hline ASSETINC & Asset income & $39,083.86$ & $4,141.02$ \\
\hline REMITTA & Remittances: income received from rural out-migrants & $35,401.28$ & $3,198.20$ \\
\hline LOANGOT & Amount of credits accessed & $7,471.43$ & $2,528.83$ \\
\hline POFFFARM & Proportion of household income derived from off-farm activities & 0.22 & 0.02 \\
\hline
\end{tabular}

SOURCE: Computed from survey data, 2006.

average of 0.36 animal units of livestock. This is equivalent to about four (4) sheep/ goats/pigs or 36 chickens.

\section{Returns to household labour use in farm and off-farm sectors}

Table 3 summarises the pattern of returns to farm and off-farm activities undertaken by members of the sampled farm households during the 2005/2006 farming season, while Table 4 present results of $\mathrm{t}$-tests/F-tests of differences between the mean incomes across different mix of livelihood strategies employed.

As shown on Table 3, 47.1\% of the sampled rural farm households derived some income from off-farm labour sources, with only $10.1 \%$ having at least one member engaged in formal employment. With regards to the relative contributions of the various labour and non-labour income sources to an average rural farm household's income, 
Table 2 Distribution of sampled farm households by membership composition

\begin{tabular}{|c|c|c|c|c|c|c|}
\hline \multirow[t]{2}{*}{ Description } & \multicolumn{2}{|c|}{ Ogun } & \multicolumn{2}{|c|}{ Oyo } & \multicolumn{2}{|c|}{ Total } \\
\hline & No & $\%$ & No & $\%$ & No & $\%$ \\
\hline \multicolumn{7}{|l|}{ Household size } \\
\hline$\cdot 1-4$ & 89 & 35.5 & 96 & 40.3 & 185 & 37.8 \\
\hline$\cdot 5-8$ & 121 & 48.2 & 115 & 48.3 & 236 & 48.3 \\
\hline - 9 or more & 41 & 16.3 & 27 & 11.3 & 68 & 13.9 \\
\hline Total & 251 & 100 & 238 & 100 & 489 & 100 \\
\hline Mean household size & 6.09 & & 5.55 & & 5.83 & \\
\hline Mean No. of economically active members & 3.22 & & 2.85 & & 3.04 & \\
\hline \multicolumn{7}{|l|}{ Farm size (Hectares) } \\
\hline - At most 1 & 91 & 36.3 & 113 & 47.5 & 204 & 43.9 \\
\hline$\cdot 1-3$ & 126 & 50.2 & 101 & 42.4 & 227 & 44.9 \\
\hline - Above 3 & 34 & 13.5 & 24 & 10.1 & 58 & 11.2 \\
\hline Total & 251 & 100 & 238 & 100 & 489 & 100 \\
\hline Mean farm size & 1.92 & & 1.73 & & 1.83 & \\
\hline \multicolumn{7}{|l|}{ Tree crop share of farm land } \\
\hline • None & 84 & 33.5 & 78 & 32.8 & 162 & 33.1 \\
\hline - At most 50\% & 101 & 40.2 & 79 & 33.2 & 180 & 36.8 \\
\hline - Above 50\% & 66 & 26.1 & 81 & 35 & 147 & 30.1 \\
\hline Total & 251 & 100 & 238 & 100 & 489 & 100 \\
\hline \multicolumn{7}{|l|}{ Livestock size (Animal units) } \\
\hline • None & 153 & 61 & 79 & 33.2 & 232 & 47.4 \\
\hline - Below 1 & 66 & 26.3 & 121 & 50.8 & 187 & 38.3 \\
\hline - At least 1 & 32 & 12.7 & 38 & 16 & 70 & 14.3 \\
\hline Total & 251 & 100 & 238 & 100 & 489 & 100 \\
\hline Mean livestock size & 0.26 & & 0.46 & & 0.36 & \\
\hline
\end{tabular}

SOURCE: Field survey, 2006.

results on Table 3 shows that labour supplied to the non-farm sector by members of the sampled rural farm household accounted for $27.6 \%$ of the farm households labour based income (estimated at $\mathrm{N} 282,263.54$ per annum) and 21.9\% of gross income (estimated at $¥ 356,748.68$ per annual). Arable crop production accounted for the largest share of an average sampled farm household's annual gross income (30.6\%) as well as total labour income (38.7\%), followed by tree crops production. Overall, efforts put into the household farms yielded an average of $\mathrm{A} 175,638.21$ per annum per household, accounting for $49.2 \%$ of an average farm household's annual gross income and $62.2 \%$ of total income from members work efforts.

As shown in Table 4, ANOVA results show that significant differences exists at $\mathrm{p}<0.01$ between the mean farm income of some categories of the sampled rural farm households when grouped across the kind of farm enterprise they were involved in during the 2005/ 2006 production season. Results of Duncan multiple range tests show that the sampled farm households may be classified into three homogeneous subsets, distinguished on the table by superscripts a, b and c. Households that cultivated both arable and tree crops recorded the highest mean farm income $(\AA 230,586.35)$ and fell in the highest income group while those that focused on tree crops and/or livestock only recorded the lowest income $(\mathrm{N} 61,556.07)$ fell in the least farm income group. 
Table 3 Descriptive statistics of contributions of labour and non-labour sources to farm households' income

\begin{tabular}{|c|c|c|c|c|c|c|c|c|}
\hline \multirow[t]{2}{*}{ Income source } & \multicolumn{4}{|c|}{$\begin{array}{l}\text { Households deriving } \\
\text { income from source }\end{array}$} & \multicolumn{4}{|c|}{$\begin{array}{l}\text { Income per average } \\
\text { household in the entire sample }\end{array}$} \\
\hline & Number & $\%$ & $\begin{array}{l}\text { Avg. } \\
\text { receipt }\end{array}$ & Std. error & Mean & Std. error & $\begin{array}{c}\% \text { of } \\
\text { GTA }\end{array}$ & $\begin{array}{l}\% \text { of } \\
\text { TLS }\end{array}$ \\
\hline \multicolumn{9}{|l|}{ Household farms } \\
\hline Arable crop production & 480 & 98.1 & $111,281.26$ & $6,602.30$ & $109,141.24$ & $6,561.58$ & 30.6 & 38.7 \\
\hline Tree crops production & 263 & 53.8 & $86,767.81$ & $5,185.84$ & $57,984.26$ & $4,477.04$ & 16.3 & 20.5 \\
\hline Livestock production & 229 & 46.8 & $14,755.36$ & $1,767.86$ & $8,512.71$ & $1,137.22$ & 2.4 & 3.0 \\
\hline $\begin{array}{l}\text { Sub-total } \\
\text { (Household farms) }\end{array}$ & 489 & 100.0 & $175,638.21$ & $7,684.42$ & $175,638.21$ & $7,684.42$ & 49.2 & 62.2 \\
\hline $\begin{array}{l}\text { Add: Natural resource } \\
\text { collection }\end{array}$ & 115 & 23.6 & $40,724.10$ & $7,159.62$ & $9,593.66$ & $2,059.84$ & 2.7 & 3.4 \\
\hline Agro-processing & 82 & 16.8 & $86,154.40$ & $11,807.07$ & $14,497.13$ & $2,978.50$ & 4.1 & 5.1 \\
\hline $\begin{array}{l}\text { Labour on others' } \\
\text { farms }\end{array}$ & 85 & 17.3 & $26,348.45$ & $6,813.71$ & $4,560.31$ & $1,355.97$ & 1.3 & 1.6 \\
\hline $\begin{array}{l}\text { Sub total } \\
\text { (Farm sector) }\end{array}$ & 489 & 100.0 & $204,289.30$ & $8,574.58$ & $204,289.31$ & $8,574.57$ & 57.3 & 72.4 \\
\hline Artisanship \& Craft & 94 & 19.2 & $149,417.81$ & $12,120.70$ & $28,734.19$ & $4,698.43$ & 8.1 & 10.2 \\
\hline Trading & 109 & 22.2 & $112,817.49$ & $10,011.92$ & $24,950.02$ & $3,925.55$ & 7.0 & 8.8 \\
\hline Formal employment & 49 & 10.1 & $175,620.31$ & $32,551.50$ & $17,730.90$ & $4,884.71$ & 5.0 & 6.3 \\
\hline $\begin{array}{l}\text { Other non-farm labour } \\
\text { sources }\end{array}$ & 37 & 7.6 & $85,268.60$ & $12,615.72$ & $6,559.12$ & $1,838.80$ & 1.8 & 2.3 \\
\hline $\begin{array}{l}\text { Sub total } \\
\text { (Non-farm sector) }\end{array}$ & 230 & 47.1 & $165,496.33$ & $12,706.03$ & $77,974.23$ & $8,283.25$ & 21.9 & 27.6 \\
\hline $\begin{array}{l}\text { Total Labour } \\
\text { Sources (TLS) }\end{array}$ & 489 & 100.0 & $282,263.54$ & $10,978.18$ & $282,263.54$ & $10,978.19$ & 79.1 & 100.0 \\
\hline Add: Remittances & 320 & 65.4 & $54,143.14$ & $4,058.35$ & $35,401.28$ & $3,198.20$ & 9.9 & \\
\hline $\begin{array}{l}\text { Income generating } \\
\text { assets }\end{array}$ & 334 & 68.3 & $57,249.60$ & $5,431.39$ & $39,083.86$ & $4,141.02$ & 11.0 & \\
\hline $\begin{array}{l}\text { Grand Total, All } \\
\text { Sources (GTA) }\end{array}$ & 489 & 100.0 & $356,748.68$ & $12,389.87$ & $356,748.68$ & $12,389.87$ & 100.0 & \\
\hline
\end{tabular}

Similar analysis in respect of off-farm labour supply mix also shows that significant differences exist at $\mathrm{p}<0.01$ between the mean off-farm income some groups of the sampled rural farm households. Farm households that had at least one members involved in paid employment in addition to trading and/or artisanship recorded the highest off-farm income ( $₫ 357,269.22)$, and were placed in a separate (and the highest) off-farm income group, based on results of Duncan multiple range tests. Meanwhile, farm households whose members concentrated on only one line of off-farm activities except paid employment (i.e. artisanship only, trading only or services only) fell in the lowest off-farm income group. Furthermore, result of t-test conducted in respect of total labour income shows that farm households whose members participated in off-farm activities recorded, on the average, an annual labour income of $\mathrm{A} 383,162.75$, which is significantly higher at $\mathrm{p}<0.01$ than the $\mathrm{A} 192$, 371.76 recorded by those whose members' efforts were concentrated on farming activities only.

ANOVA results also show that significant differences exist in the mean gross income of farm households that derived their income from different mix of labour use, income 
Table 4 Results of F/t-tests of differences in mean income across investment and labour use patterns

\begin{tabular}{|c|c|c|c|c|}
\hline Description & $\mathbf{N}$ & $\%$ & Mean & Std. error \\
\hline \multicolumn{5}{|l|}{ Farm income by farm enterprise mix } \\
\hline Arable crops only & 82 & 16.8 & $142,215.80^{\mathrm{a}, \mathrm{b}}$ & $17,590.50$ \\
\hline Arable \& tree crops & 122 & 25.0 & $230,586.35^{c}$ & $15,658.46$ \\
\hline Arable crops \& livestock & 75 & 15.4 & $138,596.11^{\mathrm{a}, \mathrm{b}}$ & $15,680.56$ \\
\hline Arable crops, tree crops \& livestock & 200 & 40.9 & $175,099.07^{b, c}$ & $11,727.26$ \\
\hline Tree crops and/or livestock & 9 & 1.9 & $61,556.07^{\mathrm{a}}$ & $22,466.14$ \\
\hline \multicolumn{5}{|l|}{ F-value $=6.587 ; p<0.01$} \\
\hline \multicolumn{5}{|l|}{ Off-farm labour Income by activity mix } \\
\hline Artisanship & 61 & 26.5 & $153,977.53^{\mathrm{a}, \mathrm{b}}$ & $15,767.33$ \\
\hline Trading & 70 & 30.6 & $121,573.38^{a, b}$ & $13,528.98$ \\
\hline Paid Job & 26 & 11.3 & $196,092.74^{b}$ & $52,361.29$ \\
\hline Other services & 28 & 12.2 & $91,293.44^{a}$ & $16,134.62$ \\
\hline Artisanship, trading and/or other service & 21 & 9.2 & $193,644.16^{b}$ & $30,030.38$ \\
\hline Paid job + trading/artisanship & 23 & 10.2 & $357,269.22^{c}$ & $57,770.53$ \\
\hline \multicolumn{5}{|l|}{ F-value $=9.228 ; p<0.01$} \\
\hline \multicolumn{5}{|l|}{ Total labour income by labour use mix } \\
\hline Farming only & 259 & 52.9 & $192,371.76^{a}$ & $12,097.18$ \\
\hline Farm and off-farm activities & 230 & 47.1 & $383,162.75^{b}$ & $16,937.51$ \\
\hline \multicolumn{5}{|l|}{$\mathrm{t}$-value $=9.166 ; \mathrm{p}<0.01$} \\
\hline \multicolumn{5}{|l|}{ Gross income by income source mix } \\
\hline Labour only & 52 & 10.6 & $266,766.86^{\mathrm{a}}$ & $30,367.86$ \\
\hline Labour \& remittances & 104 & 21.2 & $339,215.71^{\mathrm{a}, \mathrm{b}}$ & $26,224.03$ \\
\hline Labour \& asset & 120 & 24.5 & $356,064 \cdot 14^{b}$ & $27,998.20$ \\
\hline Labour, asset \& remittances & 214 & 43.7 & $387,364.01^{\mathrm{b}}$ & $21,238.92$ \\
\hline F-value $=2.538 ; p<0.10$ & & & & \\
\hline
\end{tabular}

NOTE: Mean incomes within each socio-economic group that carry the same superscript, a b or c are not significantly different, while those having different superscripts are significantly different at $p<0.05$.

generating assets and remittances at $10 \%$ level of significance. Result of Duncan multiple range tests show that the mean income of those households that relied solely on their members labour, on the average, is significantly lower at $\mathrm{p}<0.05$ than the average income of those households that, in addition to their members labour, also owned some income generating assets. Evidence in respect of farm households that received some remittances, however, showed that such receipt did not significantly raise the affected farm households' gross income above what was obtained by other comparable households without such remittances.

Overall, results on Table 4 provide some important insight into appropriate strategies for raising income level among rural farm households in the study area. First, some level of household labour use diversification both within agriculture and into off-farm activities might be necessary, not only for income risk reduction, but also for significant increases in rural farm households' income. Note that apart from the seasonal nature of agricultural production in Nigeria, the fact that most farm households operates small landholdings make off-farm diversification almost inevitable if full employment is to be guaranteed. 
Second, the fact that those households whose members were able to gain access to paid employment, recorded significantly higher income than their peers whose members could not suggests that creation of appropriate opportunities for the establishment of industries and other employment generating institutions in the rural areas may be a veritable strategy for raising rural household income. Furthermore, given that farm households that owned some income generating assets earned significantly higher income than their peers who do not, governments' may have to come up with policies and programmes that provide support for wealth creation among the rural folks as part of its overall poverty eradication strategies.

\section{Econometric results}

The central theme of this study has been to examine the implications of off-farm labour supply by members of farm household on household production efficiency. The results, based on specification and joint estimation of a conditional revenue function and a production (economic) inefficiency model using the parametric - Stochastic Frontier approach of Battesse and Coelli (1995) is presented Table 5.

Evidence from the generalised likelihood ratio test of the one-sided error term confirms that substantial inefficiency exists in the allocation of production resources, including labour, by farm households in the sample, and by extension the study area: The calculated Chi-square value was 235.4 as against the critical value of 32.00 at $\mathrm{p}<0.01$ and 16 degrees of freedom. This shows that the OLS version of the conditional revenue frontiers is not an adequate representation of the study data. The joint MLE of the revenue frontier and inefficiency model is therefore, a much more appropriate framework for analysing the production systems of farm household in the study area.

The coefficient of gamma $\left(\gamma=\sigma_{U}^{2} /\left(\sigma_{\mathrm{V}}{ }^{2}+\sigma_{\mathrm{U}}{ }^{2}\right)\right.$, which measures the proportion of the total variance $\left(\sigma^{2}=\sigma_{\mathrm{V}}{ }^{2}+\sigma_{\mathrm{U}}^{2}\right)$ that is due to inefficiency in the production system was found to be 0.99 and is significant at $\mathrm{p}<0.01$. This shows clearly that variation in income of farm households in the study area, conditional on their resource endowment, is predominantly due to inefficiency in their allocation of production resources.

\section{Income response to resource use and prices}

The top part of Table 5 presents coefficients of explanatory variables in the conditional revenue frontier of farm households in the study area; which are the partial income (revenue) elasticity with respect to changes the variables in the model. Virtually all the variables except LNPYAM, LNTLAND and LNCHLAB were associated with the apriori expected positive signs, meaning that increase in their values is associated with increase in farm household income. Examination of $\mathrm{t}$-ratio associated with the coefficients of variables in the MLE version of the conditional revenue frontiers shows that it is only the influence of five variables - LNPOIL, LNCLAND, LNANU, LNHRLAB and LNADLAB that were significant.

Only one out of the five variables depicting vector of prices, LNPOIL (price of palm oil, proxy for price of output from tree crops), had coefficient that was significant at $\mathrm{p}<0.05$. The non-significance of coefficient of other price variables may be because the study was based on a cross-section data, typically characterised by minimal level of variation in prices across observation points. The coefficient of LNPOIL is 0.43 , which shows that $1 \%$ increase in the farm gate price of products from tree crops (specifically, oil palm: which 
Table 5 Estimates of the Stochastic Revenue Frontier and inefficiency model

\begin{tabular}{|c|c|c|c|c|}
\hline & \multicolumn{2}{|c|}{ OLS estimates } & \multicolumn{2}{|c|}{ ML Estimates } \\
\hline & Coefficient & t-ratio & Coefficient & t-ratio \\
\hline \multicolumn{5}{|c|}{ Conditional revenue frontier } \\
\hline Constant & 1.6742 & 0.53 & $9.5649^{* * *}$ & 7.21 \\
\hline LNPCAS & $0.5010^{* * *}$ & 2.78 & 0.1074 & 0.86 \\
\hline LNPMAIZE & $0.3527^{*}$ & 1.79 & 0.2384 & 1.52 \\
\hline LNPYAM & $-0.4067^{* *}$ & -2.16 & -0.0534 & -0.38 \\
\hline LNPEGGS & $1.4744^{* * *}$ & 3.57 & 0.2035 & 0.68 \\
\hline LNPPOIL & 0.1742 & 0.74 & $0.4268^{* *}$ & 2.71 \\
\hline LNCLAND & $0.3815^{* * *}$ & 9.42 & $0.7075^{* * *}$ & 15.92 \\
\hline LNTLAND & $0.1795^{* * *}$ & 7.86 & -0.0309 & -0.79 \\
\hline LNANU & $0.0595^{* *}$ & 1.97 & $0.0836^{* * *}$ & 3.82 \\
\hline LNFERT & 0.0103 & 0.37 & 0.0286 & 1.57 \\
\hline LNTRACT & $0.0667^{*}$ & 1.85 & 0.0370 & 1.47 \\
\hline LNMATCOS & $0.0145^{*}$ & 1.66 & 0.0050 & 0.77 \\
\hline LNHRLAB & $0.0264^{* * *}$ & 2.98 & $0.0112^{* *}$ & 2.05 \\
\hline LNADLAB & $0.2326^{* * *}$ & 3.28 & $0.1128^{* * *}$ & 2.89 \\
\hline LNCHLAB & $0.0272^{* *}$ & 2.01 & -0.0054 & -0.48 \\
\hline \multicolumn{5}{|l|}{ Inefficiency equation } \\
\hline Constant & & & $0.2696^{* * *}$ & 4.31 \\
\hline GENDER & & & -0.0719 & -0.98 \\
\hline NATIVITY & & & -0.0351 & -0.85 \\
\hline HIGHEDU & & & -0.0012 & -0.22 \\
\hline YOUTHFAC & & & 0.0114 & 0.19 \\
\hline GENDERFA & & & -0.0482 & -0.74 \\
\hline PTREE & & & $-1.7265^{* * *}$ & -7.43 \\
\hline PFREHOLD & & & $0.1471^{* * *}$ & 2.78 \\
\hline SIMPSON & & & $0.2182^{* * *}$ & 3.08 \\
\hline DISTANCE & & & 0.0028 & 0.25 \\
\hline ASSETINC & & & $-3.3 e-7^{*}$ & -1.66 \\
\hline REMITTA & & & 0.4257 & 0.95 \\
\hline LOANGOT & & & $-6.8 e-7$ & -1.27 \\
\hline POFFFARM & & & $-0.1595^{* * *}$ & -15.24 \\
\hline Sigma squared & 0.2169 & & $0.0661^{* * *}$ & 9.43 \\
\hline Gamma & & & $0.99^{* * * *}$ & 17702 \\
\hline Log likelihood function & -129.73 & & -12.03 & \\
\hline LR test of one sided error & & & 235.4 & \\
\hline
\end{tabular}

NOTE: ${ }^{* *},{ }^{* *}$ and $*$ imply the associated coefficients are significant at $1 \%, 5 \%$ and $10 \%$ levels respectively.

was the most widely cultivated tree crops by farm households in the study area) is associated with about $0.43 \%$ increase in income of farm households.

Two out of the three coefficients associated with variables on farm size, LNCLAND and LNANU representing size of land devoted to arable crops production and stock of livestock raised by the farm households respectively, were positive and significant at $\mathrm{p}<0.01$. This shows that increase in size of arable crops and livestock farms raised by the farm households are associated with significant increases in their income. One 
per cent increase in farmland devoted to arable crops production is associated with about $0.71 \%$ increase in farm household income. Similar increase in stock of livestock was found to be associated with about $0.08 \%$ increase in farm household income. The fact that coefficient of LNTLAND (size of farmland devoted to tree crops production) is negative and not significant suggests that further increase in size of tree crop farm being cultivated by an average farm household in the sample, ceteris paribus, may not results in improvement in her income.

Focusing on the use of modern inputs / capital items like fertilizer (LNFERT), tractors services (LNTRACT) and intermediate inputs like seed, feed, etc. (LNMATCOS), results on Table 5 shows that none of the associated coefficients was significant even at $\mathrm{p}<0.10$. This outcome is not unlikely to be because the use of these inputs by farm households in the study area was very limited, and probably not in line with recommendations. It is also worthy of note that majority of the rural farm households in the sample that raised livestock kept their animals on a free range system, with little or no feed provided. The results with respect to labour use shows that farm household income is significantly affected by hired labour use (HRLAB) and numbers of economically active adults in the household (LNADLAB). One per cent increase in hired labour use is associated with about $0.01 \%$ increase in income while similar increase in the number of economically active adults in the household is associated with about $0.11 \%$ increase in farm household income.

Table 6 presents selected indicators of production (income) response to changes in various factors. It shows that partial elasticity of output response was highest with respect to increase in arable crop land cultivated, followed the number of economically active adults in the households. The overall elasticity of output response (return to scale) was found to be 0.949 ; meaning that $1 \%$ increase in use of all factors will lead to about $0.95 \%$ increase in farm household income.

Comparing the value of marginal products of the various factors, evaluated at the geometric mean of the variables in the revenue frontier with the estimated unit cost of each input, evidence on Table 6 suggests excessive use of both household and hired labour in the production system. Note, for example, that at the margin, $\mathrm{N} 1.00$ spent in employing hired labour yielded a marginal income of just about $₫ 0.63$, while an

Table 6 Selected indicators of production response to factor use

\begin{tabular}{lcccc}
\hline Production factor & $\begin{array}{c}\text { Partial } \\
\text { elasticity }\end{array}$ & $\begin{array}{c}\text { Geometric } \\
\text { mean }\end{array}$ & $\begin{array}{c}\text { Value of marginal } \\
\text { product }\end{array}$ & $\begin{array}{c}\text { Estimated unit } \\
\text { factor cost (N) }\end{array}$ \\
\hline Arable crop land $(\mathrm{Ha})$ & 0.7075 & 0.8263 & $191,383.23$ & $\mathrm{n} / \mathrm{a}$ \\
Tree crop land $(\mathrm{Ha})$ & -0.0309 & 0.2333 & $-29,604.58$ & $\mathrm{n} / \mathrm{a}$ \\
Size of livestock (ANU) & 0.0836 & 0.2276 & $82,101.14$ & 30,000 \\
Fertilizer (50 kg-bag) & 0.0286 & 0.2298 & $27,818.34$ & 2,400 \\
Tractor services (workdays) & 0.0370 & 0.1849 & $44,728.05$ & 15,000 \\
Intermediate materials (N) & 0.0050 & $1,056.18$ & 1.06 & 1.00 \\
Hired Labour cost & 0.0112 & $3,995.07$ & 0.63 & 1.00 \\
Number of adult workers & 0.1128 & 1.8547 & $13,594.10$ & $\mathrm{n} / \mathrm{a}$ \\
Number of supporting child & -0.0054 & 0.2936 & $-4,111.05$ & $\mathrm{n} / \mathrm{a}$ \\
Returns to scale & $\mathbf{0 . 9 4 9 4}$ & & &
\end{tabular}

NOTE: Values of marginal products were evaluated at the geometric mean level of each factor and output (household labour income). The geometric mean output was found to be $\mathrm{N} 223,519.38$. 
increase in the number of economically active adult in the farm household by one person will only cause income to be raised, at the margin, by N13, 954 per year showing that labour use in their production system is excessive. Contrarily, marginal returns to the use of modern inputs like fertilizer, tractor services and intermediate materials were all greater than the respective unit factor costs, showing that capital items were underutilised.

The main implication of these results is that farm household would fare better if they employ more capital items and reduce the level of their labour use in their production system. It also points to the possibility that massive rural out-migration by youths in the study area might be a response to poor marginal returns to labour use in both farm and off-farm activities in the study area.

\section{Production efficiency estimates}

Table 7 presents the distribution of the efficiency indices ${ }^{\text {a }}$ computed for each farm household in the sample. It shows that most (70.5\%) of the farm households had production efficiency index that was below 0.2 with a mean of 0.18 . It thus imply that an average farm household in the sample can have her income raised by more than five times the present level if the limiting factors are mitigated.

Comparing the production efficiency indices across farm household categories based on whether their members participated or did not participate in the rural non-farm sector, results on Table 7 shows that an average household whose members participated in off-farm activities was significantly $(\mathrm{p}<0.01)$ more efficient $(\mathrm{PE}=0.2114)$ than her counterpart whose members focused their attention only on activities in the farm sector $(\mathrm{PE}=0.1374)$. It thus imply that access to off-farm employment opportunities can, ceteris paribus, help raise production efficiency of rural farm households in the study area. The efficiency gain can enable such farm households to regain as much as $7.4 \%$ of the frontier (potential) income or $53.9 \%$ of what would have been obtained if their members did not participate in off-farm activities.

Table 7 Distribution of sampled farm households by level of production efficiency and source of livelihood

\begin{tabular}{|c|c|c|c|c|c|c|}
\hline \multirow{3}{*}{$\begin{array}{l}\text { Level of farm } \\
\text { household } \\
\text { production } \\
\text { efficiency }\end{array}$} & \multicolumn{4}{|c|}{ Households that derived their labour based income from: } & \multirow{2}{*}{\multicolumn{2}{|c|}{$\begin{array}{l}\text { All farm household } \\
\text { in the sample }\end{array}$}} \\
\hline & \multicolumn{2}{|c|}{ Farm sector only } & \multicolumn{2}{|c|}{ Farm and non-farm sectors } & & \\
\hline & No & $\%$ & No & $\%$ & No & $\%$ \\
\hline Below 0.10 & 121 & 46.7 & 47 & 20.5 & 168 & 34.3 \\
\hline $0.10-<0.20$ & 90 & 34.8 & 87 & 37.8 & 177 & 36.2 \\
\hline $0.20-<0.30$ & 28 & 10.8 & 49 & 21.3 & 77 & 15.7 \\
\hline $0.30-<0.40$ & 10 & 3.9 & 20 & 8.7 & 30 & 6.2 \\
\hline $0.40-<0.50$ & 5 & 2.0 & 18 & 7.9 & 23 & 4.8 \\
\hline 0.50 \& higher & 5 & 1.9 & 9 & 3.9 & 14 & 2.9 \\
\hline Total & 259 & 100.0 & 230 & 100 & 489 & 100 \\
\hline Mean & \multicolumn{2}{|c|}{0.1374} & \multicolumn{2}{|c|}{0.2114} & \multicolumn{2}{|c|}{0.1782} \\
\hline Std. error of mean & \multicolumn{2}{|c|}{0.0073} & \multicolumn{2}{|c|}{0.0095} & \multicolumn{2}{|c|}{0.0061} \\
\hline
\end{tabular}

NOTE: The calculated t-value in a test of difference between the mean production efficiency of the two categories of farm households was 6.18 as against a critical t-value of 2.58 at $p<0.01$ and 487 degree of freedom. 


\section{Determinants of inefficiency in the production system}

The lower section of Table 5 presents coefficients of variables in the inefficiency equation and their associated t-ratios. It shows that coefficients associated with five out of the 14 variables - PTREE, PFREHOLD, SIMPSON, ASSETINC and POFFFAM were significant. Coefficient of PTREE is negative and significant at $\mathrm{p}<0.01$ level, which means that the higher the proportion of the cultivated farmland devoted to tree crops production the lower is the inefficiency in the production system adopted by farm households. This result may appear to be a sharp contrast to earlier evidence that coefficient of LNTLAND (area of land devoted to tree crops production) was negative and insignificant in the revenue frontier. However, the import of these results is that while raising areas of land devoted to tree crops production when all other things are held constant would bring no improvement to household income, converting some areas of land from arable to tree crops production would lead to significant improvement in household income. This evidence would suggest that the tendency to convert tree crop estates to arable crop farms in search of short-term funds, would amount to greater inefficiency in farm households' resource use. It is instructive to note that, until very recent times, the proportion of arable land devoted to permanent crops production in Nigeria had been on a steady decline, dropping from about 9.1\% in 1980 steadily to about 8.36\% in 1995 (FAO, 2014). However, the trend is being reversed in recent times, with total area devoted to permanent crops growing from about 3 million hectares in 1995 to 3.2 million hectares in 2011 (FAO, 2014) in response to policy reforms.

Focusing on other variables in the inefficiency model, results on Table 5 show that coefficient of PFREEHOLD as well as SIMPSON (Simpson index, measuring the extent of farm fragmentation) were positive and significant at $\mathrm{p}<0.01$. This shows that cultivation of fragmented landholdings by rural farm households and increase in rights on land are associated with significant increases in inefficiency in the production system. The results in respect of farm fragmentation is not unexpected: evidence in literature (e.g. Blarel et al., 1992) have shown, among others, that cultivation of fragmented landholdings raises operation costs, leads to loss of time spent commuting between parcels, makes mechanisation (and therefore, deriving the associated economies of size) difficult.

The fact that farm households with higher level of rights / control on their farmland were associated with significantly higher level of inefficiency, however, goes against apriori expectations. A-priori, it is expected that farm households that enjoys greater security on their farmland are more likely to invest on land development, which could make such households to operate at higher levels of production efficiency (Chavas et al., 2005). This outcome may however, not be unconnected with the fact that most freely held land by farm households in the study area was acquired by inheritance. Meanwhile, land tenure system dominated by land ownership through inheritance has been a major cause of farm fragmentation in Africa (Blarel et al., 1992).

Coefficients of ASSETINC and POFFFARM were significant and associated with negative signs indicating that an increase in each of these variables is associated with lower production inefficiency. In other words, raising the level of income that rural farm household derive from non-labour sources, particularly income yielding assets and off-farm activities, raises production efficiency of rural farm households. This outcome supports suggestions in literature (e.g. Chavas et al., 2005; Hazell and Hojjati, 
1995) that in the presence of poorly functioning capital markets, cash from off-farm earnings (including asset income and off-farm employment income) can help stimulate farm investments and improve agricultural productivity.

Meanwhile, coefficient of REMITTA (remittances received from members of rural farm families that have migrated to the urban centre) was not significant even at $\mathrm{p}<0.10$. This shows that while increase in off-farm earnings and asset income enhances production efficiency of rural farm households in the study area, increase in the quantum of remittances they receive from their members that have migrated away to the urban centre exercise insignificant influence on their production efficiency. It is also instructive to note that coefficient of LOANGOT (amount of credit secured by the rural farm households, which was predominantly from informal sources) is also not significant; although it is associated with the desirable negative sign that suggests that access to credits tends to lower production inefficiency.

Overall, analysis of production system of rural farm households in the study area shows that substantial inefficiency exists in their allocation of production resources. Labour, including household and hired labour, is over-utilised, while modern inputs like fertilizer, tractor services, etc. are underutilised. The level of the rural farm households' production efficiency is enhanced by adoption of a diversified portfolio of income sources vis-à-vis diversification of labour use to include farm and off-farm activities, raising proportion of tree crops on their farms and investment in income yielding assets. It is instructive to note that relative influence of within farm sector diversification (e.g. raising the shares of tree crops and livestock in the farm holdings) is much stronger than the influence of diversification into off-farm labour supply. A plausible explanation for this is the fact that rates of returns to household labour use in most of the available rural non-farm activities is much lower than what obtains from labour supply/investment in tree cropping (mostly cash crops) and livestock production (Shittu, 2011). Hence, observed diversification into rural non-farm economic activities in the area are largely out of necessity (distress-push) rather than as a response to remunerative wage employment and high return off-farm business opportunities (demand-pull).

Another important evidence is that production efficiency at the farm level is enhance if the farm households operates a much more consolidated landholdings, just as raising the proportion of leased land (as against freehold land) brings about greater production efficiency. Meanwhile, household composition and personal factors like education level, gender and nativity of household heads as well as gender/youth factors in the households exercise little or no influence on production efficiency of rural farm households in the study area.

\section{Conclusions}

This central theme of this study has been to examine the influence of off-farm labour supply among members of rural farm households on farm household production efficiency in Southwest Nigeria. The study was based on primary data collected from a cross-section of 489 rural farm households, drawn by multi-stage random sampling from Ogun and Oyo States, in the Southwest rain-forest zone of Nigeria. The data was analysed by descriptive and econometric techniques, including specification and estimation of a conditional revenue frontier and a production inefficiency equation. 
The results showed that $47.1 \%$ of the rural farm households had some of their members involved in off-farm activities with a typical member devoting $34.3 \%$ of his/her work efforts to off farm activities, while off farm activities contributed $27.6 \%$ of a typical farm household's labour income (N282, 263.54 in 2005/2006). Increase in off-farm labour supply was found to be associated with significant $(\mathrm{p}<0.01)$ reduction in production in-efficiency among the rural farm households. The study also found that farm household production efficiency is significantly enhanced by increasing the share of tree crops and livestock in farm household farming activities, having access to land by leasing and operating a much more consolidated landholdings. However, remittances from rural out-migrants do not significantly affect rural farm household production efficiency.

Two main conclusions may be drawn from evidences in the study. First, availability of urban-type employment opportunities and increased participation of farm household members in the rural non-farm sector contribute significantly to farm household income and significantly enhance production efficiency. The patterns and returns to these off-farm activities, however, suggest they are economically motivated response to inadequate access to production resources and poverty within the rural farm sector. This is because returns to labour allocated to off-farm activities in the rural sector was found to be lower, on the average, than what obtains in agriculture. This shows that more attention still need to be focused at understanding and developing the rural non-farm sector in Nigeria to make activities in the sector much more rewarding and attractive to the unemployed/underemployed youths and landless households.

Second, substantial inefficiency exists in the allocation of production resources by farm households in the study area. Labour, including household and hired labour, is over utilised, while modern inputs like fertilizer, tractor services, etc. are underutilised. The level of the rural farm households' production efficiency is enhanced by adoption of a diversified portfolio of income sources vis-à-vis diversification of labour use to include farm and off-farm activities, raising proportion of tree crops and livestock on their farms, investment in income yielding assets, and by operating a much more consolidated landholding.

\section{Endnotes}

${ }^{a}$ Efficiency estimates associated with the revenue frontier are estimates of overall economic efficiency. Meanwhile, the Battesse and Coelli (1995) version of the frontier model is such that allocative efficiency is imposed in an attempt to obtain an efficient and consistent estimates of the parameters of the model (See: Coelli, 1996: pg 6). The implication of this is that efficiency estimates obtained may also be interpreted in the realm of technical efficiency.

\footnotetext{
Abbreviations

ADLAB: Number of economically active adults; ANOVA: Analysis of Variance; ANU: Animal unit; ASSETINC: Asset income: CHLAB: Number of children (<18 years) supporting income generating activities; DFID: Department for International Development of the United Kingdom; FAO: Food and Agriculture Organisation of the United Nations; FOS: Federal Office of Statistics (FOS); FERT: Quantify of fertilizer; FSIZECRP: Size of arable crop farm; FSIZETRE: Size of tree crop farm; GENDERFA: Proportion of females in the household; HIGHEDU: Years of schooling by the most educated worker in the household; HRLAB: Hired labour cost; LOANGOT: Amount of credits accessed; MATCOS: Cost of other intermediate materials; MLE: Maximum Likelihood Estimator; NBS: National Bureau of Statistics (NBS); PE: Production (Technical) Efficiency; PEGGS: Price of eggs; PFREHOLD: Proportion of farmland on freehold; PGARRI: Price of garri; PMAIZE: Price of maize grain; POFFFARM: Proportion of household income derived from off-farm activities; POIL: Price of palm oil; PTREE: Proportion of farmland devoted to tree crops; PYAM: Price of yam; REMITTA: Remittances: income received from rural out-migrants; SIMPSON: Simpson index measure of farm fragmentation; TRACTDAY: Tractor services used; USAID: United State Agricultural
} 
and Industrial Development; UNDP: United Nations Development Programme (UNDP); YOUTHFAC: Proportion of youths (15 - 30 years) in the household.

\section{Authors' contributions}

The research from which this paper was written was conceived, designed and implemented by AM in pursuit of PhD (Agricultural Economics) at the Department of Agricultural Economics and Farm Management, Federal University of Agriculture, Abeokuta, Nigeria. He solely undertook the drafting and revision of the paper, and submitted it for publication. He read and approved the final manuscript.

\section{Author's Information}

Adebayo Musediku Shittu is an Associate Professor of Agricultural \& Resource Economics in the Department of Agricultural Economics and Farm Management, Federal University of Agriculture, Abeokuta (FUNAAB), Nigeria. Degrees earned include B.Agric in Agricultural Economics and Farm Management from Ogun State University (Now Olabisi Onabanjo University), Ago-Iwoye (1992), MSc Agricultural Economics from the University of Ibadan, Nigeria (1995), and PhD Agricultural Economics from FUNAAB (2008). Research interests include applied microeconomic analysis, economics of natural resources, environment and development. He has to his credit over 30 articles published in local and international journals. He is a member of International Association of Agricultural Economists, Agricultural and Applied Economics Association, Association of Environmental and Resource Economists, Northeastern Agricultural and Resource Economics Association, and Farm Management Association of Nigeria. He has mentored over 100 undergraduate \& postgraduate students, and currently functions as a Part-time Consultant to Lagos State Fadama III Project Coordinating Office.

\section{Acknowledgements}

The author wish to acknowledge the very useful comments and suggestions of members of AM's PhD thesis Supervisory Committee - Professors DAO Phillip, S Momoh and SO Apantaku, to the design and implementation of the study that served as basis for writing up this paper. The author was also an employee of Olabisi Onabanjo University, Ago-Iwoye while conducting the PhD research. The research was however, solely funded by the author. The author also wishes to acknowledge the very useful comments and suggestions of the anonymous reviewers as well as editorial comments of the Handling Editor. These contributed immensely to the quality of the final output of the paper.

Received: 17 October 2013 Accepted: 20 April 2014

Published online: 12 July 2014

References

Anderson D, Leiserson MW (1984) Rural Nonfarm Employment in Developing Countries. Econ Dev Cult Change 28:227248

Babatunde RO, Qaim M (2010) Impact of off-farm income on food security and nutrition in Nigeria. Food Policy 35 (4):303-311. doi:10.1016/j.foodpol.2010.01.006

Babatunde RO, Olorunsanya EO, Adejola AD (2008) Assessment of Rural Household Poverty: Evidence from Southwestern Nigeria. American-Eurasian J Agric \& Environ Sci 3(6):900-905

Battese GE, Coelli TJ (1995) A Model for Technical Inefficiency Effects in a Stochastic Frontier Function for Panel Data. Empir Econ 20:325-332

Blarel B, Hazell P, Place F, Quiggin J (1992) The Economics of Farm Fragmentation: Evidence from Ghana and Rwanda. The World Bank Econ Rev 6(2):233-254

Chang H, Mishra A (2008) Impact of off-farm labor supply on food expenditures of the farm household. Food Pol 33 (6):657-664. doi:10.1016/j.foodpol.2008.02.002

Chang H, Wen F (2011) Off-farm work, technical efficiency, and rice production risk in Taiwan. Agric Econ 42(2):269-278. doi:10.1111/j.15740862.2010.00513.x

Chavas J, Petrie R, Roth M (2005) Farm Household Production Efficiency: Evidence from the Gambia. Am J Agric Econ $87(1): 160-179$

Coelli TJ (1996) A Guide to Frontier 4.1: A Computer Program for Stochastic Frontier Production and Cost Function Estimation. In: CEPA Working Paper 96/07. Centre for Efficiency and Productivity Analysis (CEPA), University of New England, Australia

Department for International Development of the United Kingdom (DFID) (2004) Rural Urban Development Case Study - Nigeria. Oxford Policy Management, Oxford, United Kingdom

Escobal J (2001) The determinants of non-farm income diversification in rural Peru. World Dev 29(3):497-508

Federal Office of Statistics (FOS) (1999) Poverty and Welfare in Nigeria. FOS, Nigeria

Food and Agriculture Organisation (FAO) (1998) The State of Food and Agriculture. FAO Series No 31, FAO, Rome, Italy

Food and Agriculture Organisation (FAO) (2014) FAOSTAT data. FAOSTAT data. FAO, Rome, Italy. http://faostat3.fao.org/ faostat-gateway/go/to/download/R/RL/E. Accessed 25 Mar 2014

Goldsmith PD, Gunjal K, Ndarishikanye B (2004) Rural-urban Migration and Agricultural Productivity: the case of Senegal. Agric Econ 31:33-45

Haggblade S, Hazell P, Reardon T (2010) The Rural Non-farm Economy: Prospects for Growth and Poverty Reduction. World Dev 38(10):1429-1441

Hazell P, Hojjati B (1995) Farm/Non-farm Growth Linkages in Zambia. Journal of African Economies 4(3):406-435

Holden S, Shiferaw B, Pender J (2004) Non-farm income, household welfare, and sustainable land management in a less-favoured area in the Ethiopian highlands. Food Pol 29(4):369-392. doi:10.1016/j.foodpol.2004.07.007

Huang J, Wu Y, Rozelle S (2009) Moving off the farm and intensifying agricultural production in Shandong: a case study of rural labor market linkages in China. Agric Econ 40:203-218 
Jacoby HG (1993) Shadow Wages and Peasant Family Labor Supply: Application to the Peruvian Sierra. Rev Econ Stud 60:903-921

Lanjouw P (2000) Non-farm Employment and Poverty in Rural El Salvador. World Dev 23(3):529-547

Lanjouw J, Lanjouw P (2001) Rural Non-farm Employment: A Survey. Agric Econ 26:1-23

Lien G, Kumbhakar SC, Hardaker JB (2010) Determinants of off-farm work and its effects on farm performance: the case of Norwegian grain farmers. Agric Econ 41(6):577-586. doi:10.1111/j.1574-0862.2010.00473.x

Matshe I, Young T (2004) Off-farm Labour Allocation Decisions in Small-scale Rural Households in Zimbabwe. Agric Econ 30:175-186

National Bureau of Statistics (NBS) (2011) National average of the indicator. "Unemployment Rates by State" in the Data Category - "Socio-Economic Data", NBS, Nigeria. Available at: http://nigeria.prognoz.com/en/DataAnalysis

National Bureau of Statistics (NBS) (2012) Press Briefing by the Statistician-General of the Federation/Chief Executive Officer. In: National Bureau of Statistics. Dr. Yemi Kale held at the Conference Room, 5th Floor, NBS Headquarters, Central Business District, Abuja on Monday, 13th February, 2012. NBS, Abuja, Nigeria. Available at: http://www. proshareng.com/reports/4632

Newman JL, Gertler PJ (1994) Family Productivity, Labor Supply, and Welfare in a Low Income Country. J Hum Resour 29:989-1026

Ogwumike OF, Aromolaran AB (2000) Poverty Dynamics in Nigeria. World Bank, Rome

Okali D, Okpara E, Olawoye J (2001) Rural-urban Interactions and Livelihood Strategies: The case of Aba and its region, southeastern Nigeria. Working Paper Series on Rural-urban Interactions and Livelihood Strategies, Human Settlements Programme, IIED, October

Owusu V, Abdulahi A, Abdul-Rahman S (2011) Non-farm work and food security among farm households in Northern Ghana. Food Pol 36(2):108-118

Pfeiffer L, L'opez-Feldman A, Taylor JE (2009) Is off-farm income reforming the farm? Evidence from Mexico. Agric Econ 40:125-138

Phimister E, Roberts D (2006) The Effect of Off-farm Work on the Intensity of Agricultural Production. Environ Resour Econ 34(4):493-515

Schultz TW (1990) Restoring Economic Equilibrium. Basil Black Well, Cambridge

Shi X, Heerink N, Qu F (2011) Does off-farm employment contribute to agriculture-based environmental pollution? New insights from a village-level analysis in Jiangxi Province, China. China Econ Rev 22(4):524-533

Shittu AM (2011) Off-farm Labour Drift in the Sub-Saharan Africa: Patterns, Determinants and Production Efficiency Outcomes in Southwest. LAP Lambert Academic Publishing, Germany, Nigeria

Shittu AM, Ashaolu OF, Odusanya OS (2006) Off-farm Labour Participation and Farm Household Livelihood Strategy in Yewa Division, Ogun State, Nigeria. FAMAN Journal 8(1):64-70

Stampini M, Davis B (2009) Does nonagricultural labor relax farmers' credit constraints? Evidence from longitudinal data for Vietnam. Agric Econ 40:177-188

United Nations Development Programme (UNDP) (2010) The Real Wealth of Nations: Pathways to Human Development (Human Development Report 2010). UNDP, New York

United State Agricultural and Industrial Development (USAID) (2002) Urban Profile - Nigeria. USAID, USA

Wandschneider T (2003) Determinants of access to rural non-farm employment. In: Evidence from Africa, South Asia and transition economies. NRI Report No 2758, Natural Resource Institute, University of Greenwich, United Kingdom

World Bank (2000) World Development Report 2000: Attacking Poverty. World Bank, Washington, D.C

doi:10.1186/s40100-014-0008-z

Cite this article as: Shittu: Off-farm labour supply and production efficiency of farm household in rural Southwest

Nigeria. Agricultural and Food Economics 2014 2:8.

\section{Submit your manuscript to a SpringerOpen ${ }^{\circ}$ journal and benefit from:}

- Convenient online submission

- Rigorous peer review

- Immediate publication on acceptance

- Open access: articles freely available online

- High visibility within the field

- Retaining the copyright to your article

Submit your next manuscript at $\boldsymbol{s p r i n g e r o p e n . c o m ~}$ 